Article

\title{
Exploitable Lipids and Fatty Acids in the Invasive Oyster Crassostrea gigas on the French Atlantic Coast
}

\author{
Flore Dagorn ${ }^{1}$, Aurélie Couzinet-Mossion ${ }^{1}$, Melha Kendel ${ }^{1}$, Peter G. Beninger ${ }^{2,+}$, \\ Vony Rabesaotra ${ }^{1}$, Gilles Barnathan ${ }^{1, *,+}$ and Gaëtane Wielgosz-Collin ${ }^{1,+}$ \\ 1 Faculté des Sciences Pharmaceutiques et Biologiques, Université de Nantes, Groupe Mer, Molécules, \\ Santé-EA 2160, Institut Universitaire Mer et Littoral FR3473 CNRS, 9 rue Bias, BP 53508, \\ F-44035 Nantes Cedex 1, France; flore.dagorn@gmail.com (F.D.); \\ aurelie.couzinet-mossion@univ-nantes.fr (A.C.-M.); melha.kendel@gmail.com (M.K.); \\ vony.rabesaotra@univ-nantes.fr (V.R.); Wielgosz-Collin@univ-nantes.fr (G.W.-C.) \\ 2 Faculté des Sciences et des Techniques, Université de Nantes, Groupe Mer, Molécules, Santé-EA 2160, \\ Institut Universitaire Mer et Littoral FR34473 CNRS, 2 rue de La Houssinière BP 92208, \\ F-44322 Nantes Cedex 3, France; Peter.Beninger@univ-nantes.fr \\ * Correspondence: gilles.barnathan@univ-nantes.fr; Tel.: +33-251-125-689 \\ + These authors contributed equally to this work.
}

Academic Editor: Andrew Desbois

Received: 12 February 2016; Accepted: 16 May 2016; Published: 24 May 2016

\begin{abstract}
Economic exploitation is one means to offset the cost of controlling invasive species, such as the introduced Pacific oyster (Crassostrea gigas Thunberg) on the French Atlantic coast. Total lipid and phospholipid (PL) fatty acids (FAs) and sterols were examined in an invasive population of C. gigas in Bourgneuf Bay, France, over four successive seasons, with a view to identify possible sources of exploitable substances. The total lipid level (\% dry weight) varied from $7.1 \%$ (winter) to $8.6 \%$ (spring). Of this, PLs accounted for $28.1 \%$ (spring) to $50.4 \%$ (winter). Phosphatidylcholine was the dominant PL throughout the year (up to $74 \%$ of total PLs in winter). Plasmalogens were identified throughout the year as a series of eleven dimethylacetals (DMAs) with chain lengths between $C_{16}$ and $\mathrm{C}_{20}$ (up to $14.5 \%$ of PL FAs + DMAs in winter). Thirty-seven FAs were identified in the PL FAs. Eicosapentaenoic acid (20:5n-3 EPA/7.53\% to $14.5 \%$ ) and docosahexaenoic acid (22:6n-3 DHA/5.51\% to $9.5 \%$ ) were the dominant polyunsaturated FAs in all seasons. Two non-methylene-interrupted dienoic (NMID) FAs were identified in all seasons: 7,13-docosadienoic and 7,15-docosadienoic acids, the latter being present at relatively high levels (up to $9.6 \%$ in winter). Twenty free sterols were identified, including cholesterol at $29.9 \%$ of the sterol mixture and about $33 \%$ of phytosterols. C. gigas tissues thus contained exploitable lipids for health benefits or as a potential source of high-quality commercial lecithin.
\end{abstract}

Keywords: Crassostrea gigas; fatty acids; health and nutrition; bivalve; mollusc; non-methylene interrupted fatty acids; plasmalogens; phospholipids; seasonal variations

\section{Introduction}

The Pacific oyster, Crassostrea gigas, was introduced for cultivation to the French Atlantic coasts in the 1970s to replace the Portuguese oyster Crassostrea angulata, which was decimated by two epidemics in the 1960s [1]. With the subsequent increase in near-shore seawater temperatures, cultured populations began to extensively colonize the French Atlantic coast, even fouling the oyster-farming sites themselves [2-6], with biomasses exceeding $50 \mathrm{~kg} \cdot \mathrm{m}^{-2}$ [6]. Among the most affected sites, invasive $C$. gigas is reported to constitute more than $70 \%$ of the total oyster biomass of the commercial oyster-producing Bourgneuf Bay $[3,7,8]$. Since the invasive and the cultured C. gigas are 
sympatric, it is certain that trophic competition also takes place, negatively affecting the oyster-culture potential. Profitable exploitation is a possible cost-effective avenue of remediation here and in the other C. gigas-invaded habitats.

In a previous study, we showed the potential economic value of another invasive species, Crepidula fornicata, which contained high added-value lipids such as a marine lecithin rich in phosphatidylcholine, and $n-3$ polyunsaturated fatty acids (PUFAs) [9]. Long-chain $n-3$ PUFAs, mainly eicosapentaenoic acid (EPA) and docosahexaenoic acid (DHA), are dietary lipids with an array of health benefits throughout life $[10,11]$. Phospholipid (PL)-bound n-3 PUFAs are of high nutritional value because of they are as bioavailable as their counterparts in conventional fish oils where $n-3$ PUFAs are bound to triacylglycerols [12]. PUFA supply from aquaculture sources has also increased over the past decades, making up for the shortfalls from fishery supplies $[13,14]$. Although EPA and DHA are known to be beneficial in the prevention or treatment of several diseases [15], levels of DHA and EPA are often low in Western diets [16]. This has led to the commercialization of EPA-DHA supplements, which thus consume even more of the dwindling fish oil resource [14]. Although the lipid and fatty acid contents of C. gigas have been investigated previously, these studies were either confined to specific body parts [17], or preliminary analyses showed that we could achieve comparatively finer resolution [18-20]. We therefore present the results of a detailed study of the wild C. gigas lipids, with a view to the future simultaneous exploitation and remediation of the invasive populations.

\section{Results and Discussion}

\subsection{Seasonal Lipid Content and Lipid Class Composition}

Total tissue lipid contents (\% dry weight, DW) and percentages of the main lipid classes of C. gigas over the four seasons are reported in Table 1.

Table 1. Seasonal total tissue lipid content (TL) (\% DW) and lipid class composition (\% TL) of Crassostrea gigas. Values are the mean of three replicates (mean \pm standard deviation).

\begin{tabular}{ccccc}
\hline Collection Season & Total Lipids (\% DW) & Neutral Lipids (\% TL) & Glycolipids (\% TL) & Phospholipids (\% TL) \\
\hline Winter (January) & $7.1 \pm 0.5$ & $40 \pm 1$ & $9 \pm 2$ & $50.4 \pm 0.4$ \\
Spring (April) & $8.6 \pm 0.2$ & $64.5 \pm 0.7$ & $7.4 \pm 0.7$ & $28.1 \pm 0.9$ \\
Summer (July) & $7.9 \pm 0.1$ & $39.3 \pm 0.4$ & $12.4 \pm 0.4$ & $48.0 \pm 0.5$ \\
Autumn (November) & $8.1 \pm 0.4$ & $50.3 \pm 0.9$ & $10.4 \pm 0.8$ & $39.3 \pm 0.4$ \\
\hline
\end{tabular}

Lipid content varies only slightly throughout the year, from 7.1\% (winter) to 8.6\% DW (spring). Similar seasonal variations (from $7.8 \%$ to $8.7 \%$ DW) were observed for C. gigas introduced and farmed in Irish waters [21]. However, seasonal variations may be more pronounced if the species is cultured off-shore ( $8 \%$ to $14 \%$ DW) [20].

In the present study, non-polar lipids (triacylglycerols, sterols and free fatty acids) (FAs) accounted for $40 \%$ (winter) to $64.5 \%$ (spring) of total lipids, while PL levels occurred at $50.4 \%$ in winter and $28.1 \%$ in spring. Glycolipids ranged from $7.4 \%$ (spring) to $12.4 \%$ (summer). These high proportions of neutral lipids (NLs) and PLs are in agreement with the literature [20,22,23].

\subsection{Seasonal Phospholipid Class Composition}

Throughout the year, phosphatidylcholine (PC) was the main PL class, at 39.7\% to $74 \%$ of total PLs, the highest level being observed in winter (Table 2). The lowest level observed in spring is in accordance with values reported for C. gigas harvested in France at the same season [23,24]. To our knowledge, a seasonal variation of PL class composition has never been reported for C. gigas.

The commercially active component of lecithin is PC. However, commercial 'lecithin' is often simply a mixture of PLs with a relatively high PC content, of unspecified FA chain length. In contrast, the Crassostrea gigas PLs contain a high percentage of PC, as well as long-chain PUFAs, such that the PLs may be considered a potential source of high-quality lecithin. 
Table 2. Seasonal phospholipid class composition of Crassostrea gigas (\% phospholipids). Values are the mean of three replicates (mean \pm standard deviation).

\begin{tabular}{ccccc}
\hline Phospholipid Class & Winter & Spring & Summer & Autumn \\
\hline Cardiolipin & $6.8 \pm 0.3$ & $10.7 \pm 0.3$ & $7.2 \pm 0.6$ & $4.9 \pm 0.5$ \\
Phosphatidylethanolamine & $4.3 \pm 0.2$ & $18 \pm 2$ & $6.3 \pm 0.3$ & $5.3 \pm 0.3$ \\
Ceramide aminoethylphosphonate & $10 \pm 1$ & $24 \pm 1$ & $24.6 \pm 0.4$ & $22 \pm 1$ \\
Phosphatidylserine & $1.6 \pm 0.9$ & $4.0 \pm 0.1$ & $3.2 \pm 0.4$ & $5.7 \pm 0.2$ \\
Phosphatidylcholine & $74 \pm 4$ & $39.7 \pm 0.4$ & $53.2 \pm 0.3$ & $58.6 \pm 0.6$ \\
Lysophosphatidylcholine & $2.9 \pm 0.3$ & $3.8 \pm 0.9$ & $5.4 \pm 0.5$ & $3.3 \pm 0.5$ \\
\hline
\end{tabular}

Lysophosphatidylcholine was present at $2.9 \%$ to $5.4 \%$, suggesting the occurrence of phospholipases in all seasons. Phosphatidylserine ranged from $1.6 \%$ (winter) to $5.7 \%$ (autumn). Phosphatidylinositol and phosphatidylglycerol were not observed in the samples; this was verified using two-dimensional thin-layer chromatography against known standards. Interestingly, cardiolipin (CL) occurred in all seasons at significant levels $(4.9 \%-10.7 \%)$. In mammalian tissues, CL is found almost exclusively in the inner mitochondrial membranes, mediating various respiratory functions $[25,26]$. The occurrence and possible functions of CL has been studied in detail in some marine bivalves, including Pecten maximus, Mytilus edulis and C. gigas, which contain a unique CL with four docosahexaenoyl chains; it is suggested that this is a specific adaptation in bivalves in response to variations in environmental conditions [27].

The unusually high levels of ceramide aminoethylphosphonate (CAEP) in all seasons except winter (up to $24.6 \%$ of PLs) are notable. This phosphonosphingolipid is widely distributed among molluscs [28], including in C. gigas tissues and especially hemocytes [29,30]. Throughout the year, the levels of phosphatidylethanolamine (PE) were surprisingly low (approx. 4\%-18\%) in Crassostrea gigas, compared to previously published data for other marine bivalves $(32 \%-41 \%$, [31]). However, our results report significant levels of $\mathrm{CL}$, as well as twice as much CAEP, suggesting that the disparity may be methodological.

\subsection{Seasonal Phospholipid Fatty Acid Composition}

Fatty acid (FA) composition, determined as fatty acid methyl esters (FAMEs), is given in Table 3. In addition to the FAMEs, the resulting mixture also contained eleven fatty aldehyde dimethylacetals (DMAs), which were readily identified from their mass spectra showing a characteristic intense fragment ion at $m / z 75\left(\left[\left(\mathrm{CH}_{3} \mathrm{O}\right)_{2}-\mathrm{CH}\right]^{+}\right)$and an ion corresponding to $[\mathrm{M}-31]^{+}[9,31]$. Thirty-eight FAs with chain lengths between $\mathrm{C}_{14}$ and $\mathrm{C}_{24}$ were identified in the PLs.

The PL FA mixture consisted of SFAs (29.6\% to $40.7 \%$ of the total FA + DMA mixture), MUFAs $(19.5 \%-23.4 \%)$, PUFAs $(34.5 \%-38.7 \%)$, and DMAs (3.8\%-14.5\%). SFAs included the dominant palmitic acid (14.6\%-23.8\%) and several branched FAs, including iso and anteiso FAs. The 11-18:1, 11-20:1 and 13-20:1 acids were the most abundant among the monounsaturated FAs. The level of 11-18:1 acid was relatively steady at $4.5 \%$ to $5.7 \%$, except in spring where it dropped to $2.5 \%$. Similarly, the level of 13-20:1 remained between $5.4 \%$ and $5.8 \%$, except in spring where it decreased to $2.2 \%$. On the contrary, the 11-20:1 acid had its highest level in spring (7.2\%). This corresponds to the period in which C. gigas gametogenesis is initiated at this site [32].

The conventionally dominant PUFAs, eicosapentaenoic 20:5n-3 (EPA), and 22:6n-3 (DHA) acids, were present in all seasons at high levels, from $7.5 \%$ (summer) to $14.5 \%$ (spring) and $5.5 \%$ (spring) to $9.5 \%$ (summer), respectively. The percentage of $n-3$ PUFAs was markedly higher than that of $n-6$ PUFAs. According to literature (Table 4), EPA and DHA levels in oyster lipids (TLs or PLs) varied greatly depending on harvesting country, temperature and season. EPA levels varied from $7.6 \%$ to $22.4 \%$ in PLs described in literature and from $7.5 \%$ to $15.4 \%$ in the present study, which is in the same order of magnitude. DHA highest percentages (35.8\% TLs and 32.5\% PLs) were analyzed in oysters collected in warm water during winter $[33,34]$ but lower levels, more in agreement with the present study, were described in oysters from Europe. The data presented here thus agree with those of the 
literature, and confirm that these $n$-3 PUFA levels appear typical of $C$. gigas. The abundant invasive oyster biomass could thus be a useful source of $n-3$ PUFAs, which appear to have positive clinical effects [15].

Table 3. Seasonal levels of phospholipid fatty acids of Crassostrea gigas. ${ }^{a}$ ECLs (equivalent chain lengths) were determined using a CP-Sil 5 column CB. $i$, iso; ai, anteiso; br, branched.

\begin{tabular}{|c|c|c|c|c|c|}
\hline \multirow{2}{*}{ Fatty Acids (Symbol) } & \multirow{2}{*}{$\mathrm{ECL}^{\mathrm{a}}$} & \multicolumn{4}{|c|}{ Abundance (wt \%) } \\
\hline & & Winter & Spring & Summer & Autumn \\
\hline \multicolumn{6}{|c|}{ Saturated Fatty Acids (SFAs) } \\
\hline $14: 0$ & 14.00 & $1.05 \pm 0.01$ & $2.1 \pm 0.1$ & $1.46 \pm 0.01$ & $1.75 \pm 0.04$ \\
\hline 4,8,12--Me $-13: 0$ & 14.49 & $0.3 \pm 0.1$ & $2.2 \pm 0.1$ & $1.73 \pm 0.04$ & $1.06 \pm 0.04$ \\
\hline $15: 0$ & 15.00 & $1.2 \pm 0.1$ & $0.56 \pm 0.09$ & $0.61 \pm 0.01$ & $1.28 \pm 0.01$ \\
\hline$i-16: 0$ & 15.60 & $0.5 \pm 0.1$ & $*$ & $0.52 \pm 0.02$ & $0.44 \pm 0.01$ \\
\hline $16: 0$ & 16.00 & $14.6 \pm 0.5$ & $16.8 \pm 0.06$ & $23.8 \pm 0.1$ & $19.1 \pm 0.3$ \\
\hline$i-17: 0$ & 16.64 & $1.08 \pm 0.01$ & $0.5 \pm 0.03$ & $1.24 \pm 0.03$ & $0.84 \pm 0.01$ \\
\hline $17: 0$ & 17.00 & $2.8 \pm 0.4$ & $1.41 \pm 0.01$ & $1.64 \pm 0.03$ & $2.4 \pm 0.1$ \\
\hline 2-OH-16:0 & 17.18 & $1.6 \pm 0.1$ & $1.7 \pm 0.1$ & $0.9 \pm 0.03$ & $1.99 \pm 0.07$ \\
\hline$i-18: 0$ & 17.64 & $0.36 \pm 0.01$ & $0.31 \pm 0.01$ & $0.88 \pm 0.01$ & $0.57 \pm 0.02$ \\
\hline 18:0 & 18.00 & $5 \pm 0.1$ & $5.6 \pm 0.2$ & $7.32 \pm 0.03$ & $5.8 \pm 0.2$ \\
\hline Total SFAs & & $28.5 \pm 0.7$ & $31.2 \pm 0.4$ & $40.1 \pm 0.1$ & $35.2 \pm 0.7$ \\
\hline \multicolumn{6}{|c|}{ Monounsaturated fatty acids (MUFAs) } \\
\hline 9-16:1 & 15.74 & $1.75 \pm 0.01$ & $1.9 \pm 0.1$ & $1.18 \pm 0.02$ & $3.16 \pm 0.01$ \\
\hline 7-Me-6(Z)-16:1 & 16.20 & $0.32 \pm 0.01$ & n.d. & n.d. & $0.20 \pm 0.01$ \\
\hline 7-Me-6(E)-16:1 & 16.53 & $0.65 \pm 0.01$ & $0.22 \pm 0.01$ & $0.36 \pm 0.03$ & $0.42 \pm 0.02$ \\
\hline 9-18:1 & 17.76 & $2.8 \pm 0.1$ & $0.94 \pm 0.05$ & $4.78 \pm 0.04$ & $2.41 \pm 0.07$ \\
\hline $11-18: 1$ & 17.81 & $4.5 \pm 0.1$ & $5.8 \pm 0.2$ & $2.46 \pm 0.03$ & $5.72 \pm 0.06$ \\
\hline 3-19:1 & 18.58 & $1.6 \pm 0.1$ & $1.53 \pm 0.05$ & $1.36 \pm 0.01$ & $2.5 \pm 0.01$ \\
\hline 11-20:1 & 19.68 & $1.6 \pm 0.1$ & $3.34 \pm 0.07$ & $7.19 \pm 0.03$ & $2.94 \pm 0.03$ \\
\hline 13-20:1 & 19.73 & $5.8 \pm 0.2$ & $5.43 \pm 0.05$ & $2.16 \pm 0.01$ & $5.8 \pm 0.1$ \\
\hline Total MUFAs & & $19.0 \pm 0.5$ & $19.2 \pm 0.6$ & $19.5 \pm 0.05$ & $23.2 \pm 0.3$ \\
\hline \multicolumn{6}{|c|}{ Polyunsaturated fatty acids (PUFAs) } \\
\hline $18: 4 n-3$ & 17.54 & $1.01 \pm 0.01$ & $0.9 \pm 0.02$ & $1.00 \pm 0.01$ & $0.9 \pm 0.01$ \\
\hline $18: 2 n-6$ & 17.66 & $0.3 \pm 0.1$ & $0.84 \pm 0.04$ & $2.84 \pm 0.05$ & $0.67 \pm 0.01$ \\
\hline $20: 4 n-6$ & 19.24 & $4.2 \pm 0.1$ & $2.07 \pm 0.01$ & $3.35 \pm 0.04$ & $3.67 \pm 0.01$ \\
\hline $20: 5 n-3$ & 19.34 & $9.3 \pm 0.1$ & $14.5 \pm 0.1$ & $7.53 \pm 0.03$ & $9.54 \pm 0.01$ \\
\hline $20: 3 n-7$ & 19.49 & $0.5 \pm 0.01$ & $0.73 \pm 0.03$ & $0.40 \pm 0.01$ & $0.45 \pm 0.01$ \\
\hline $20: 2 n-9,12$ & 19.52 & $0.9 \pm 0.1$ & $1.28 \pm 0.04$ & $1.10 \pm 0.01$ & $1.06 \pm 0.05$ \\
\hline $22: 6 n-3$ & 21.12 & $7.8 \pm 0.2$ & $5.51 \pm 0.09$ & $9.50 \pm 0.03$ & $7.72 \pm 0.09$ \\
\hline $22: 4 n-6$ & 21.19 & $1.42 \pm 0.01$ & $1.4 \pm 0.05$ & $2.36 \pm 0.01$ & $1.17 \pm 0.06$ \\
\hline $22: 5 n-3$ & 21.28 & $0.38 \pm 0.01$ & $0.30 \pm 0.01$ & $0.45 \pm 0.01$ & $0.37 \pm 0.01$ \\
\hline $22: 2 n-9,15$ & 21.40 & $1.31 \pm 0.01$ & $0.99 \pm 0.01$ & $1.98 \pm 0.02$ & $1.1 \pm 0.01$ \\
\hline $22: 2 n-7,15$ & 21.46 & $9.6 \pm 0.3$ & $9.02 \pm 0.13$ & $4.74 \pm 0.05$ & $7.4 \pm 0.2$ \\
\hline Total PUFAs & & $36.7 \pm 0.7$ & $37.5 \pm 0.5$ & $35.2 \pm 0.3$ & $34.1 \pm 0.6$ \\
\hline \multicolumn{6}{|c|}{ Fatty aldehyde dimethylacetals (DMAs) } \\
\hline $16: 0$ & 16.48 & $0.68 \pm 0.01$ & $0.56 \pm 0.08$ & $0.25 \pm 0.01$ & $0.39 \pm 0.02$ \\
\hline br-17:0 & 17.12 & $0.8 \pm 0.1$ & $0.39 \pm 0.04$ & $0.24 \pm 0.01$ & $0.28 \pm 0.04$ \\
\hline br-17:0 & 17.22 & $0.25 \pm 0.01$ & * & $0.27 \pm 0.01$ & $0.2 \pm 0.01$ \\
\hline 17:0 & 17.48 & $0.83 \pm 0.01$ & $0.59 \pm 0.08$ & $*$ & $0.49 \pm 0.07$ \\
\hline br-18:0 & 18.10 & $0.9 \pm 0.1$ & n.d. & n.d. & n.d. \\
\hline br-18:0 & 18.22 & $0.82 \pm 0.01$ & $0.39 \pm 0.02$ & n.d. & $0.38 \pm 0.03$ \\
\hline 18:0 & 18.48 & $6.6 \pm 0.2$ & $6 \pm 2$ & $1.49 \pm 0.02$ & $2.97 \pm 0.03$ \\
\hline br-19:0 & 19.22 & $0.33 \pm 0.01$ & $0.19 \pm 0.01$ & $*$ & $0.26 \pm 0.02$ \\
\hline br-20:1 & 20.06 & $1 \pm 0.1$ & $0.42 \pm 0.06$ & * & $0.28 \pm 0.06$ \\
\hline br-20:1 & 20.10 & $0.41 \pm 0.01$ & $0.37 \pm 0.08$ & $0.49 \pm 0.01$ & $0.59 \pm 0.09$ \\
\hline 20:0 & 20.17 & $1.9 \pm 0.2$ & $1.66 \pm 0.04$ & $0.65 \pm 0.02$ & $0.63 \pm 0.03$ \\
\hline Total DMAs & & $14.5 \pm 0.4$ & $10.6 \pm 0.2$ & $3.39 \pm 0.05$ & $6.5 \pm 0.3$ \\
\hline
\end{tabular}

Minor FAs as traces (<0.2\%) (ECL): $i$-15:0 (14.62); 4-16:1 (15.70); ai-17:0 (16.73); i-19:0 (18.61); ai-19:0 (18.72); br-20:0 (19.38); 21:2n-8,14 (19.91); 22:0 (22.00); 5-24:1 (23.27); 24:0 (24.00). Values are the means of three replicates (mean \pm standard deviation. n.d., not detected, and ${ }^{*}<0.2 \%$ ). 
Surprisingly, the third most abundant FA in PLs was a non-methylene-interrupted (NMI) diunsaturated FA, 22:2n-7,15, occurring at 9.6\% (winter) and $9.0 \%$ (spring). Two other NMI FAs were present, $22: 2 n-9,15(1 \%-2 \%)$ and the rare $21: 2 n-8,14$ as traces. Such diunsaturated NMI FAs occur commonly in marine invertebrates [35], especially in various molluscs, including oysters $[20,23,24,29,36]$ but generally at lower levels (Table 4 ).

Table 4. Comparison between the present study and the literature for the major PUFAs.

\begin{tabular}{cccccc}
\hline \multicolumn{1}{c}{ Species } & EPA \% TL FA & DHA \% TL FA & NMI \% TL FA & Country & References \\
\hline C. gigas & $10.8-15.2$ & $10.3-15.5$ & - & Ireland & {$[21]$} \\
C. gigas & $16.4-25.5$ & $15.6-21.3$ & $3.9-7.7$ & Germany & {$[20]$} \\
C. rhizophorae & $17.9-19.7$ & $19.7-35.8$ & - & Brazil & {$[33]$} \\
\hline Species & \% PL FA & \% PL FA & \% PL FA & Country & References \\
\hline C. gigas & $7.5-15.4$ & $5.5-9.5$ & $6.8-10.9$ & France & Present study \\
C. gigas & $13.8-22.4$ & $9.9-17.6$ & $3.3-7.3$ & Spain & {$[22]$} \\
C. gigas & 12.3 in muscle & 17.3 in muscle & 4.1 in muscle & France & {$[24]$} \\
C. gigas & $18.6-21.7$ in PC & $13.1-15.8$ in PC & $2.7-3.5$ in PC & France & {$[23]$} \\
C. corteziensis & $10.3-17.4$ & $22.5-32.5$ & $7.8-12.8$ & Mexico & {$[34]$} \\
O. edulis & $7.6-17.4$ & $8.2-18.5$ & $2.8-13$ & Spain & {$[37]$} \\
\hline
\end{tabular}

They are known to occur mainly in PLs, especially in plasmalogens (1-alkenyl-2-acyl ether glycerophospholipids) [36], shown here by eleven $\mathrm{C}_{16}$ and $\mathrm{C}_{20}$ fatty aldehyde DMAs in the lipids of C. gigas, at $0.6 \%$ to $1.9 \%$. The unusual unsaturation pattern of NMI FAs provides cell membranes with increased resistance to oxidative processes and microbial lipases, relative to the common PUFAs $[35,36,38,39]$. The sharp decrease in NMI+DMA levels observed in summer for C. gigas of the present study, contrasts with the stable levels observed throughout the year in the warm-water C. corteziensis [34].

\subsection{Free Sterol Composition}

The free sterol fraction was the main component of the neutral lipids, especially in winter. The seasonal total free sterol composition is presented in Table 5 .

Cholesterol was the most abundant sterol at relatively low levels from $21.4 \%$ (summer) to $35.8 \%$ of the unsaponifiable fraction (spring). The notable decrease in the summer value probably reflects the result of gamete emission, as was also observed for the autumn values for this species in the more southern Venice lagoon [19].

Other major sterols present were brassicasterol $(9.2 \%-12.8 \%)$, 24-methylenecholesterol (ostreasterol, 8.4\%-14\%), $\beta$-sitosterol (6.0\%-10.1\%). Previous studies on seasonal variation of sterol composition of $C$. gigas (whole body or hematocyte membranes) have reported similar results $[19,29]$ as well as studies on C. corteziensis and C. virginica [34,40]. In addition, 22E-dehydrocholesterol $(5.6 \%-8.4 \%)$, campesterol $(5.5 \%-6.9 \%)$ have also been previously described in oysters, but not cholestanol $(3.9 \%-6.7 \%)[34,40]$.

Although 4-methylsterols are well known to be typical dinoflagellate sterols, they may also be found in diatoms, and are indicative of a trophic link [41-43]. Interestingly, 4-methylsterols and $\beta$-sitosterol have hypolipidemic properties [44], suggesting another clinical use for invasive oyster biomass.

The 24-methyl- and 24-ethylsterols, known as phytosterols (campesterol, brassicasterol, sitosterol, stigmasterol), as well as other sterols branched at C-24, all have well-established cholesterol-lowering properties [45,46], through the decrease in intestinal absorption of cholesterol. Phytosterols have also been shown to benefit cardiovascular and inflammatory conditions [47]. Since humans cannot synthesize phytosterols, they must be provided in the diet, and the high levels of these molecules in C. gigas throughout the year (more than $30 \%$ ) makes them a potentially valuable source of these sterols. 
Table 5. Seasonal composition of the total free sterols of Crassostrea gigas. X1, X2: unidentified sterols; Values are the mean of three replicates (mean \pm s.d.); s.d., standard deviation; n.d., non detected. \% phytosterols calculated with respect to total sterols.

\begin{tabular}{|c|c|c|c|c|c|}
\hline \multirow{2}{*}{ Systematic Names } & \multirow{2}{*}{ Trivial Names } & \multicolumn{4}{|c|}{$\%$ Total Lipids } \\
\hline & & Winter & Spring & Summer & Autumn \\
\hline 24-nor-Cholesta-5,22E-dien-3 $\beta$-ol & 24-nor-Dehydrocholesterol & $5.2 \pm 0.1$ & $5.65 \pm 0.1$ & $3.57 \pm 0.05$ & $4.9 \pm 0.2$ \\
\hline 24-nor-5 $\alpha$-Cholest-22E-en-3 $\beta$-ol & 24-nor-Dehydrocholestanol & $0.51 \pm 0.06$ & n.d. & $0.47 \pm 0.02$ & $0.7 \pm 0.07$ \\
\hline Cholesta-5,22Z-dien-3 $\beta$-ol & 22Z-Dehydrocholesterol & $1.7 \pm 0.3$ & $1.92 \pm 0.08$ & $0.9 \pm 0.1$ & $1.7 \pm 0.2$ \\
\hline Cholesta-5,22E-dien-3 $\beta$-ol & 22E-Dehydrocholesterol & $8.94 \pm 0.07$ & $6.3 \pm 0.2$ & $5.6 \pm 0.1$ & $7.5 \pm 0.4$ \\
\hline $5 \alpha$-Cholest-22E-en-3 $\beta$-ol & 22-Dehydrocholestanol & $1.2 \pm 0.2$ & n.d. & $0.8 \pm 0.2$ & $1.4 \pm 0.2$ \\
\hline Cholest-5-en-3ß-ol & Cholesterol & $32.1 \pm 0.7$ & $35.8 \pm 0.4$ & $21.4 \pm 0.3$ & $30.3 \pm 0.4$ \\
\hline $5 \alpha$-Cholestan- $3 \beta$-ol & Cholestanol & $3.94 \pm 0.08$ & $6.7 \pm 0.7$ & $4 \pm 0.1$ & $4.7 \pm 0.2$ \\
\hline 24-Methylcholesta-5,22E-dien-3 $\beta$-ol & Brassicasterol/Crinosterol & $12.8 \pm 0.7$ & $12.6 \pm 0.3$ & $9.19 \pm 0.05$ & $10.7 \pm 0.2$ \\
\hline $4 \alpha$-Methyl-5 $\alpha$-cholest-7-en- $3 \beta$-ol & Lophenol & $0.91 \pm 0.08$ & n.d. & n.d. & n.d. \\
\hline $\mathrm{X} 1\left(\Delta^{\circ} \mathrm{C} 28: 0\right)$ & $n_{-}-$ & $0.5 \pm 0.2$ & n.d. & $1.71 \pm 0.05$ & n.d. \\
\hline 24-Methylcholesta-5,24(28)-dien-3 $\beta$-ol & 24-Methylenecholesterol & $14 \pm 0.2$ & $12.9 \pm 0.5$ & $8.35 \pm 0.03$ & $10.7 \pm 0.1$ \\
\hline 24-Methylcholest-5-en-3 $\beta$-ol & Campesterol/22,23-Dihydrobrassicasterol & $6.24 \pm 0.07$ & $6.93 \pm 0.03$ & $6 \pm 0.1$ & $5.5 \pm 0.1$ \\
\hline $5 \alpha$-24-Ethylcholest-25-en-3 $\beta$-ol & $5 \alpha$-Poriferast-25-en-3 $\beta$-ol/25-Dehydroporiferastanol & $0.53 \pm 0.07$ & n.d. & n.d. & n.d. \\
\hline $5 \alpha$-24-Ethylcholesta-22,24(25)-dien-3ß-ol & $5 \alpha$-Porifera-22,24(25)-dien-3 $\beta$-ol & $1.2 \pm 0.1$ & n.d. & $1.11 \pm 0.01$ & $1.1 \pm 0.2$ \\
\hline 24-Ethylcholest-5,22E-dien-3ß-ol & Poriferasterol/Stigmasterol & $1.78 \pm 0.03$ & $1.7 \pm 0.2$ & $1.67 \pm 0.04$ & $1.7 \pm 0.1$ \\
\hline 4,24-Dimethylcholesta-5,7,24(28)-trien-3 $\beta$-ol & 4-Methyl-5 $\alpha$-Ergosta-24(28)-en-3 $\beta$-ol & $0.4 \pm 0.03$ & n.d. & $7.8 \pm 0.1$ & $5.6 \pm 0.3$ \\
\hline 24-Ethylcholest-5-en-3 $\beta$-ol & $\beta$-Sitosterol/Clionasterol & $5.4 \pm 0.3$ & $9.9 \pm 0.5$ & $10.2 \pm 0.2$ & $6.0 \pm 0.4$ \\
\hline 24-Ethyl-5 $\alpha$-cholest-22E-en-3 $\beta$-ol & Poriferastanol/Stigmastanol & $2.8 \pm 0.2$ & $2.6 \pm 0.2$ & $1.6 \pm 0.2$ & $3.5 \pm 0.2$ \\
\hline 24-Ethylcholesta-5,24(28)-dien-3 $\beta$-ol & Fucosterol & n.d. & n.d. & $1.23 \pm 0.04$ & $0.65 \pm 0.04$ \\
\hline 4-Methyl-24-ethyl-5 $\alpha$-cholesta-7-en- $3 \beta$-ol & 4-Methyl-5 $\alpha$-Porifera-7-en-3 $\beta$-ol/24-Ethyllophenol & n.d. & n.d. & $2.90 \pm 0.05$ & $0.96 \pm 0.08$ \\
\hline $\mathrm{X} 2\left(\Delta^{\circ} \mathrm{C} 30: 0\right)$ & - & n.d. & n.d. & $0.95 \pm 0.04$ & n.d. \\
\hline 4-Methyl-24-ethyl-cholesta-5-en-3 $\beta$-ol & 4-Methyl-Porifera-5-en-3 $\beta$-ol & n.d. & n.d. & $0.73 \pm 0.09$ & $0.61 \pm 0.09$ \\
\hline$\%$ Phytosterols & & 30.8 & 33.7 & 33.4 & 30.1 \\
\hline
\end{tabular}




\section{Materials and Methods}

\subsection{Specimen Collection}

Specimens of wild Crassostrea gigas were hand-collected at an oyster-farming site, La Couplasse, in Bourgneuf Bay (French Atlantic coast, 46-47 $\mathrm{N}, 1-2^{\circ} \mathrm{W}$ ) in January, April, July and November 2007. They were immediately transported to the laboratory, where soft tissues were separated from the shells, pooled, homogenized with a blender (about $300 \mathrm{~g}$ tissue) and divided into three replicate lots. The homogenates were stored at $-20{ }^{\circ} \mathrm{C}$ prior to analyses.

\subsection{Chemicals}

Standards of PLs (cardiolipin CL, phosphatidylcholine PC, phosphatidylethanolamine PE, phosphatidylinositol PI, phosphatidylglycerol PG, phosphatidylserine PS, lysophosphatidylcholine LPC, lysophosphatidylethanolamine LPE, sphingomyelin SPH) were sourced from Sigma-Aldrich (Saint-Quentin Fallavier, France). An authentic ceramide aminoethylphosphonate (CAEP) was kindly donated by Yanic Marty (CNRS, UBO, Brest, France).

\subsection{Lipid Analyses}

\subsubsection{Total Lipid Extraction and Separation of Lipid Classes}

Lipid analyses were conducted as previously described [9]. Briefly, total lipids were extracted using dichloromethane/methanol $(1: 1, v / v)$ for $3 \mathrm{~h}$ at room temperature. After filtration on a Büchner funnel, the extract was washed with distilled water and evaporated to dryness and stored at $-20^{\circ} \mathrm{C}$ and under nitrogen prior to further analyses.

Lipid classes were separated on an open silica gel column $(290 \mathrm{~mm} \times 25 \mathrm{~mm}, 60 \AA$, $35-75 \mu \mathrm{m})$ with dichloromethane (neutral lipids), acetone (glycolipids) and methanol (PLs) as successive moving phases.

\subsubsection{High Performance Liquid Chromatography (HPLC) Analyses of Phospholipids}

A modular UltiMate 3000 RS HPLC System (Thermo Scientific, Villebon sur Yvette, France) coupled with an evaporative light scattering detector (ELSD) Sedex 85 (Sedere S.A., Alfortville, France) was used to quantify the different PL classes using standard curves $(10 \mu \mathrm{L}$ of chloroform serially diluted solutions of CL, PE, PC, PG, SPH, LPC and LPE (1-10 $\mu$ g), and CAEP, PI and PS (0.5-5 $\mu \mathrm{g})$. For ELSD, nebulizer gas pressure (dried and filtrated air) was set to 3.5 bar and the detector was heated to $50{ }^{\circ} \mathrm{C}$. The chromatographic separation was carried out using a Prevail ${ }^{\mathrm{TM}}$ silica column (150 mm $\times 4.6 \mathrm{~mm}, 3 \mu \mathrm{m}$ particle diameter, Alltech Associates Inc., Lokeren, Belgium) heated at $25^{\circ} \mathrm{C}$ with a $1.5 \mathrm{~mL} / \mathrm{min}$ flow rate. PLs were eluted using gradient elution with two solvents: chloroform (A) and methanol $/ 28 \%$ ammonia in water/chloroform $(92: 7: 1, v / v / v)(B)$. Elution began at $0 \%$, increased to $20 \%$ in $3 \mathrm{~min}$, then increased to $100 \%$ in $9 \mathrm{~min}$ and held for $3 \mathrm{~min}$. The injection volume was $10 \mu \mathrm{L}$ of a sample dilution in chloroform $(2 \mathrm{mg} / \mathrm{mL})$ and injections were performed in triplicates.

\subsubsection{Gas Chromatography-Mass Spectrometry (GC-MS)}

All FAs of the total PLs were converted to the fatty acid methyl esters (FAMEs) by transmethylation with methanolic hydrogen chloride [9]. FAMEs were then converted to $N$-acyl pyrrolidides using pyrrolidine/acetic acid $(5: 1, v / v)$ in order to locate double bonds and branching [9]. Free sterols were isolated in the unsaponifiable fraction following saponification ( $2 \mathrm{M}$ ethanolic potassium hydroxide) of neutral lipids. Sterols were converted to sterol acetates (SAs) by reaction with acetic anhydride and dried pyridine, for $12 \mathrm{~h}$ in darkness, at room temperature [48].

Separations of FAMEs, NAPs and SAs were achieved using a CP-Sil 5 CB low bleed MS capillary column (60 $\mathrm{m} \times 0.25 \mathrm{~mm}$ I.D., $0.25 \mu \mathrm{m}$ phase thickness-Chrompack, Middelburg, The Netherlands) under a constant flow rate (Helium-1 mL/min). For FAME analyses, the initial temperature of the 
GC-oven was $170{ }^{\circ} \mathrm{C}$ held for $4 \mathrm{~min}$, with a subsequent increase $\left(3^{\circ} \mathrm{C} / \mathrm{min}\right)$ to $300^{\circ} \mathrm{C}$. For NAP and SA analyses, the oven temperature was programmed at $200^{\circ} \mathrm{C}$ (kept for 4 min-NAP), then increased to $310{ }^{\circ} \mathrm{C}\left(3^{\circ} \mathrm{C} / \mathrm{min}\right)$ and maintained at this temperature for $20 \mathrm{~min}$ for the NAPs and $25 \mathrm{~min}$ for the SAs.

\subsection{Data Presentation}

Data are presented as mean percentages for three replicates. The conventional indicator of dispersion about the mean is the standard deviation; we have followed this practice in the present work while awaiting the publication of recommendations for more appropriate presentation of this general type of data [49].

\section{Conclusions}

The high levels of high-quality lecithin observed in C. gigas (from $1 \mathrm{~g}$ (in spring) to $2.6 \mathrm{~g}$ (in winter) $/ 100 \mathrm{~g}$ DW) make it a potential alternative source for commercial lecithin, a substance in high demand in the food industry [50]. This shows promise for nutritional and health applications, since a recent study has shown that marine PC rich in $n-3$ PUFAs has beneficial effects against colon cancer [51] and psoriasis [52-55]. The invasive oyster also contains lipids of interest, such as cardiolipin [56], plasmalogens and NMI FAs with effects against oxidative stress [38,39,57], $n$-3 PUFAS [58-64] and phytosterols with cholesterol-lowering effects, anti-inflammatory properties and as useful adjuvants in the reduction of cardiovascular risk [47] (Table 6).

Table 6. Potential economic, nutritional, and health benefits of $C$. gigas lipids.

\begin{tabular}{ccc}
\hline Lipids & Potential Benefits & References \\
\hline Lecithin (with & Protection against colon cancer & {$[51,54,55]$} \\
associated PUFAs) & Treatment of psoriasis & {$[52]$} \\
& High-quality source for food industry & {$[49]$} \\
\hline CAEP & Implication in some haemocyte functions & {$[28,30]$} \\
\hline \multirow{2}{*}{ Cardiolipin } & Optimization of mitochondrial respiratory & {$[56]$} \\
& performance & {$[25,26]$} \\
\hline & Improve efficacy and tolerability of cancer chemotherapy & {$[59]$} \\
$n$-3 Polyunsaturated FAs & Cancer prevention & {$[58]$} \\
(EPA, DHA) & Neuroprotective efficacy & {$[60]$} \\
& Cardiovascular disease protection & {$[61]$} \\
& Improvement of some obesity-associated metabolic & {$[62,63]$} \\
& syndrome features (Type 2 diabetes) & {$[64]$} \\
\hline Diunsaturated NMI FAs & Anti-inflammatory effect & {$[38,57]$} \\
\hline Plasmalogens & Resistance to oxidative stress and microbial lipases & {$[38,39]$} \\
\hline & Countering oxidative stress & {$[45,46]$} \\
Phytosterols & Cholesterol-lowering action & {$[47]$} \\
& Reduction in cardiovascular risk & {$[45]$} \\
\hline
\end{tabular}

This study is the second report showing the potential of an invasive mollusc as an alternative source of marine lecithin rich in PC and $n$-3 long-chain PUFAs [9]. Exploitation of this resource could constitute an avenue of remediation for these invasions.

Acknowledgments: This work is a part of Flore Dagorn's Ph.D. thesis (University of Nantes, Nantes, France, 2012) supported by a grant from the Ministère de l'Education Nationale, de la Recherche et de la Technologie, Paris, France. The authors are grateful to Yanic Marty, CNRS, University of West Brittany, Brest, France, for kindly donating pure samples of the authentic ceramide aminoethylphosphonate from Crepidula fornicata and Pecten maximus. The authors also thank Michèle Viau, UR1268, INRA, Nantes, France, for her contribution to HPLC lipid analyses. 
Author Contributions: D.F. as Ph.D. student was involved at all study stages including oyster collection and sample preparation, and data presentation and interpretation, and initial write-up. C.-M.A. participated in results analysis, including phospholipid analyses, and critical revision of the manuscript. K.M. performed the initial sample preparations and lipid analyses. R.V. contributed to lipid extractions, lipid class separations and chemical derivatizations, and performed the GC/MS analyses. B.G., B.P.G. and W.-C.G. initiated and supervised the Ph.D. thesis work of D.F. and were responsible for writing, arranging and checking the manuscript. All authors read and approved the final manuscript.

Conflicts of Interest: The authors declare no conflict of interest.

$\begin{array}{ll}\text { Abbreviations } \\ \text { CAEP } & \text { ceramide aminoethylphosphonate } \\ \text { DHA } & n \text {-3 docosahexaenoic acid } \\ \text { DMA(s) } & \text { dimethylacetal(s) } \\ \text { DW } & \text { dry weight } \\ \text { EPA } & n \text {-3 eicosapentaenoic acid } \\ \text { ELSD } & \text { evaporative light scattering } \\ \text { FA(s) } & \text { fatty acid(s) } \\ \text { FAME(s) } & \text { fatty acid methyl ester(s) } \\ \text { GC-MS } & \text { gas chromatography-mass spectrometry } \\ \text { HPLC } & \text { high performance liquid chromatography } \\ \text { LPC } & \text { lysophosphatidylcholine } \\ \text { LPE } & \text { lysophosphatidylethanolamine } \\ \text { MUFA(s) } & \text { monounsaturated fatty acid(s) } \\ \text { NAP(s) } & \text { N-acyl pyrrolidide(s) } \\ \text { NMID } & \text { non-methylene-interrupted dienoic } \\ \text { PC } & \text { phosphatidylcholine } \\ \text { PE } & \text { phosphatidylethanolamine } \\ \text { PG } & \text { phosphatidylglycerol } \\ \text { PI } & \text { phosphatidylinositol } \\ \text { PS } & \text { phosphatidylserine } \\ \text { PUFA(s) } & \text { polyunsaturated fatty acid(s) } \\ \text { PL(s) } & \text { phospholipid(s) } \\ \text { SA(s) } & \text { sterol acetate(s) } \\ \text { SFA(s) } & \text { saturated fatty acid(s) } \\ \text { SPH } & \text { sphingomyelin } \\ \text { TL } & \text { total lipids } \\ & \\ & \end{array}$

\section{References}

1. Grizel, H.; Héral, M. Introduction into France of the Japanese oyster (Crassostrea gigas). J. Cons. ICES J. Mar. Sci. 1991, 47, 399-403. [CrossRef]

2. Ruesink, J.L.; Lenihan, H.S.; Trimble, A.C.; Heiman, K.W.; Micheli, F.; Byers, J.E.; Kay, M.C. Introduction of non-native oysters: Ecosystem effects and restoration Implications. Annu. Rev. Ecol. Evol. Syst. 2005, 36, 643-689. [CrossRef]

3. Cognie, B.; Haure, J.; Barillé, L. Spatial distribution in a temperate coastal ecosystem of the wild stock of the farmed oyster Crassostrea gigas (Thunberg). Aquaculture 2006, 259, 249-259. [CrossRef]

4. Troost, K. Causes and effects of a highly successful marine invasion: Case-study of the introduced Pacific oyster Crassostrea gigas in continental NW European estuaries. J. Sea Res. 2010, 64, 145-165. [CrossRef]

5. Dutertre, M.; Beninger, P.G.; Barillé, L.; Papin, M.; Haure, J. Rising water temperatures, reproduction and recruitment of an invasive oyster, Crassostrea gigas, on the French Atlantic coast. Mar. Environ. Res. 2010, 69, 1-9. [CrossRef] [PubMed]

6. Stiger-Pouvreau, V.; Thouzeau, G. Marine species introduced on the French Channel-Atlantic coasts: A review of main biological invasions and impacts. Open J. Ecol. 2015, 5, 227-257. [CrossRef]

7. Martin, J.-L.; Haure, J.; Dupuy, B.; Nourry, M.; Palvadeau, H.; Papin, M.; Penisson, C.; Thouard, E. Estimation de Stocks D'huîtres Sauvages sur les Zones Concédées de la Partie Vendéenne de la Baie de Bourgneuf en 2003; DRV/RA/LCPL/2004-03; Ifremer: Issy-Les-Moulineaux, France, 2004.

8. Martin, J.-L.; Haure, J.; Dupuy, B.; Nourry, M.; Palvadeau, H.; Papin, M.; Penisson, C.; Thouard, E. Estimation des Stocks D’huîtres Sauvages sur les Zones non Concédées de la Partie Vendéenne de la Baie de Bourgneuf en 2004; AGS/LGP/Bouin/2005-01; Ifremer: Issy-Les-Moulineaux, France, 2005. 
9. Dagorn, F.; Buzin, F.; Couzinet-Mossion, A.; Decottignies, P.; Viau, M.; Rabesaotra, V.; Barnathan, G.; Wielgosz-Collin, G. Multiple beneficial lipids including lecithin detected in the edible invasive mollusk Crepidula fornicata from the French Northeastern Atlantic coast. Mar. Drugs 2014, 12, 6254-6268. [CrossRef] [PubMed]

10. Ruxton, C.H.S.; Reed, S.C.; Simpson, M.J.A.; Millington, K.J. The health benefits of omega-3 polyunsaturated fatty acids: A review of the evidence. J. Hum. Nutr. Diet. 2004, 17, 449-459. [CrossRef] [PubMed]

11. Swanson, D.; Block, R.; Mousa, S.A. Omega-3 fatty acids EPA and DHA: Health benefits throughout life. Adv. Nutr. Int. Rev. J. 2012, 3, 1-7. [CrossRef] [PubMed]

12. Ghasemifard, S.; Turchini, G.M.; Sinclair, A.J. Omega-3 long chain fatty acid "bioavailability": A review of evidence and methodological considerations. Prog. Lipid Res. 2014, 56, 92-108. [CrossRef] [PubMed]

13. Bergé, J.-P.; Barnathan, G. Fatty Acids from Lipids of Marine Organisms: Molecular Biodiversity, Roles as Biomarkers, Biologically Active Compounds, and Economical Aspects. Adv. Biochem. Eng. Biotechnol. 2005, 96, 49-125. [PubMed]

14. Tacon, A.G.J.; Metian, M. Global overview on the use of fish meal and fish oil in industrially compounded aquafeeds: Trends and future prospects. Aquaculture 2008, 285, 146-158. [CrossRef]

15. Martins, J. EPA but not DHA appears to be responsible for the efficacy of omega-3 LC-PUFA supplementation in depression: Evidence from an updated meta-analysis of randomized controlled trials. J. Am. Coll. Nutr. 2009, 28, 525-542. [CrossRef] [PubMed]

16. Simopoulos, A.P. The importance of the ratio of omega-6/omega-3 essential fatty acids. Biomed. Pharmacother. 2002, 56, 365-379. [CrossRef]

17. Dudognon, T.; Lambert, C.; Quere, C.; Auffret, M.; Soudant, P.; Kraffe, E. Mitochondrial activity, hemocyte parameters and lipid composition modulation by dietary conditioning in the Pacific oyster Crassostrea gigas. J. Comp. Physiol. B 2014, 184, 303-317. [CrossRef] [PubMed]

18. Chu, F.-L.E.; Webb, K.L.; Chen, J. Seasonal changes of lipids and fatty acids in oyster tissues (Crassostrea virginica) and estuarine particulate matter. Comp. Biochem. Physiol. A Mol. Integr. Physiol. 1990, 95, 385-391. [CrossRef]

19. Orban, E.; Di Lena, G.; Masci, M.; Nevigato, T.; Casini, I.; Caproni, R.; Gambelli, L.; Pellizzato, M. Growth, nutritional quality and safety of oysters (Crassostrea gigas) cultured in the lagoon of Venice (Italy). J. Sci. Food Agric. 2004, 84, 1929-1938. [CrossRef]

20. Pogoda, B.; Buck, B.H.; Saborowski, R.; Hagen, W. Biochemical and elemental composition of the offshore-cultivated oysters Ostrea edulis and Crassostrea gigas. Aquaculture 2013, 400-401, 53-60. [CrossRef]

21. Linehan, L.G.; O'Connor, T.P.; Burnell, G. Seasonal variation in the chemical composition and fatty acid profile of Pacific oysters (Crassostrea gigas). Food Chem. 1999, 64, 211-214. [CrossRef]

22. Pazos, A.J.; Ruiz, C.; Garcia-Martin, O.; Abad, M.; Sanchez, J.L. Seasonal variations of the lipid content and fatty acid composition of Crassostrea gigas cultured in El Grove, Galicia, N.W. Spain. Comp. Biochem. Physiol. B Biochem. Mol. Biol. 1996, 114, 171-179. [CrossRef]

23. Saito, H.; Marty, Y. High levels of icosapentaenoic acid in the lipids of oyster Crassostrea gigas ranging over both Japan and France. J. Oleo Sci. 2010, 59, 281-292. [CrossRef] [PubMed]

24. Soudant, P.; Van Ryckeghem, K.; Marty, Y.; Moal, J.; Samain, J.-F.; Sorgeloos, P. Comparison of the lipid class and fatty acid composition between a reproductive cycle in nature and a standard hatchery conditioning of the Pacific Oyster Crassostrea gigas. Comp. Biochem. Physiol. B Biochem. Mol. Biol. 1999, 123, $209-222$. [CrossRef]

25. Schlame, M.; Rua, D.; Greenberg, M.L. The biosynthesis and functional role of cardiolipin. Prog. Lipid Res. 2000, 39, 257-288. [CrossRef]

26. Houtkooper, R.H.; Vaz, F.M. Cardiolipin, the heart of mitochondrial metabolism. Cell. Mol. Life Sci. 2008, 65, 2493-2506. [CrossRef] [PubMed]

27. Kraffe, E.; Soudant, P.; Marty, Y.; Kervarec, N.; Jehan, P. Evidence of a tetradocosahexaenoic cardiolipin in some marine bivalves. Lipids 2002, 37, 507-514. [CrossRef] [PubMed]

28. Kariotoglou, D.M.; Mastronicolis, S.K. Sphingophosphonolipid molecular species from edible mollusks and a jellyfish. Comp. Biochem. Physiol. B Biochem. Mol. Biol. 2003, 136, 27-44. [CrossRef]

29. Le Grand, F.; Kraffe, E.; Marty, Y.; Donaghy, L.; Soudant, P. Membrane phospholipid composition of hemocytes in the Pacific oyster Crassostrea gigas and the Manila clam Ruditapes philippinarum. Comp. Biochem. Physiol. A Mol. Integr. Physiol. 2011, 159, 383-391. [CrossRef] [PubMed] 
30. Matsubara, T. The structure and distribution of ceramide aminoethylphosphonates in the oyster (Ostrea gigas). Biochim. Biophys. Acta 1975, 388, 353-360. [PubMed]

31. Hanuš, L.O.; Levitsky, D.O.; Shkrob, I.; Dembitsky, V.M. Plasmalogens, fatty acids and alkyl glyceryl ethers of marine and freshwater clams and mussels. Food Chem. 2009, 116, 491-498. [CrossRef]

32. Dutertre, M.; Beninger, P.G.; Barillé, L.; Papin, M.; Rosa, P.; Barillé, A.-L.; Haure, J. Temperature and seston quantity and quality effects on field reproduction of farmed oysters, Crassostrea gigas, in Bourgneuf Bay, France. Aquat. Living Resour. 2009, 22, 319-329. [CrossRef]

33. Lira, G.M.; Pascoal, J.C.M.; Torres, E.A.F.; Soares, R.A.M.; Mendonça, S.; Sampaio, G.R.; Correia, M.S.; Cabral, C.C.V.Q.; Cabral Júnior, C.R.; López, A.M.Q. Influence of seasonality on the chemical composition of oysters (Crassostrea rhizophorae). Food Chem. 2013, 138, 786-790. [CrossRef] [PubMed]

34. Hurtado, M.A.; Racotta, I.S.; Arcos, F.; Morales-Bojórquez, E.; Moal, J.; Soudant, P.; Palacios, E. Seasonal variations of biochemical, pigment, fatty acid, and sterol compositions in female Crassostrea corteziensis oysters in relation to the reproductive cycle. Comp. Biochem. Physiol. B Biochem. Mol. Biol. 2012, 163, 172-183. [CrossRef] [PubMed]

35. Barnathan, G. Non-methylene-interrupted fatty acids from marine invertebrates: Occurrence, characterization and biological properties. Biochimie 2009, 91, 671-678. [CrossRef] [PubMed]

36. Kraffe, E.; Soudant, P.; Marty, Y. Fatty acids of serine, ethanolamine, and choline plasmalogens in some marine bivalves. Lipids 2004, 39, 59-66. [CrossRef] [PubMed]

37. Abad, M.; Ruiz, C.; Martinez, D.; Mosquera, G.; Sánchez, J. Seasonal variations of lipid classes and fatty acids in flat oyster, Ostrea edulis, from San Cibran (Galicia, Spain). Comp. Biochem. Physiol. C Pharmacol. Toxicol. Endocrinol. 1995, 110, 109-118. [CrossRef]

38. Brites, P.; Waterham, H.R.; Wanders, R.J.A. Functions and biosynthesis of plasmalogens in health and disease. Biochim. Biophys. Acta Mol. Cell Biol. Lipids 2004, 1636, 219-231. [CrossRef] [PubMed]

39. Wang, G.; Wang, T. The role of plasmalogen in the oxidative stability of neutral lipids and phospholipids. J. Agric. Food Chem. 2010, 58, 2554-2561. [CrossRef] [PubMed]

40. Berenberg, C.J.; Patterson, G.W. The relationship between dietary phytosterols and the sterols of wild and cultivated oysters. Lipids 1981, 16, 276-278. [CrossRef]

41. Withers, N.W.; Kokke, W.; Fenical, W.; Djerassi, C. Sterol patterns of cultured zooxanthellae isolated from marine invertebrates: Synthesis of gorgosterol and 23-desmethylgorgosterol by aposymbiotic algae. Proc. Natl. Acad. Sci. USA 1982, 79, 3764-3768. [CrossRef] [PubMed]

42. Nichols, P.D.; Gary, J.J.; de Leeuw, J.W.; Johns, R.B. The fatty acid and sterol composition of two marine dinoflagellates. Phytochemistry 1984, 23, 1043-1047. [CrossRef]

43. Volkman, J.K.; Barrett, S.M.; Dunstan, G.A.; Jeffrey, S.W. Geochemical significance of the occurrence of dinosterol and other 4-methyl sterols in a marine diatom. Org. Geochem. 1993, 20, 7-15. [CrossRef]

44. Kritchevsky, D.; Tepper, S.A.; Czarnecki, S.K.; Kyle, D.J. Effects of 4-methylsterols from algae and of $\beta$-sitosterol on cholesterol metabolism in rats. Nutr. Res. 1999, 19, 1649-1654. [CrossRef]

45. Brufau, G.; Canela, M.A.; Rafecas, M. Phytosterols: Physiologic and metabolic aspects related to cholesterol-lowering properties. Nutr. Res. 2008, 28, 217-225. [CrossRef] [PubMed]

46. Do, H.Q.; Van Landeghem, L.; Wielgosz-Collin, G.; Takoudju, M.; Huvelin, J.-M.; Kornprobst, J.-M.; Bard, J.-M.; Barnathan, G.; Nazih, H. Unusual sterolic mixture, and 24-isopropylcholesterol, from the sponge Ciocalypta sp. reduce cholesterol uptake and basolateral secretion in Caco-2 cells. J. Cell. Biochem. 2009, 106, 659-665. [CrossRef] [PubMed]

47. Patch, C.; Tapsell, L.C.; Williams, P.G.; Gordon, M. Plant sterols as dietary adjuvants in the reduction of cardiovascular risk: Theory and evidence. Vasc. Health Risk Manag. 2006, 2, 157-162. [CrossRef] [PubMed]

48. Kendel, M.; Couzinet-Mossion, A.; Viau, M.; Fleurence, J.; Barnathan, G.; Wielgosz-Collin, G. Seasonal composition of lipids, fatty acids, and sterols in the edible red alga Grateloupia turuturu. J. Appl. Phycol. 2013, 25, 425-432. [CrossRef]

49. Beninger, P.G.; Boldina, I. Error bars in the environmental sciences: What to use, why and when. 2016, unpublished work.

50. List, G.R. Soybean Lecithin: Food, Industrial Uses, and Other Applications. In Polar Lipids, Biology, Chemistry, and Technology, 1st ed.; Ahmad, M.U., Xu, X., Eds.; AOCS Press: Urbana, IL, USA, 2015; pp. 1-34. 
51. Fukunaga, K.; Hossain, Z.; Takahashi, K. Marine phosphatidylcholine suppresses 1,2-dimethylhydrazineinduced colon carcinogenesis in rats by inducing apoptosis. Nutr. Res. 2008, 28, 635-640. [CrossRef] [PubMed]

52. Dupont, P. Traitement du psoriasis par la lécithine marine. Phytothérapie 2006, 4, 15-22. [CrossRef]

53. Wolters, M. Diet and psoriasis: Experimental data and clinical evidence. Br. J. Dermatol. 2005, 153, 706-714. [CrossRef] [PubMed]

54. Canty, D.J.; Zeisel, S.H. Lecithin and choline in human health and disease. Nutr. Rev. 1994, 52, 327-339. [CrossRef] [PubMed]

55. Küllenberg, D.; Taylor, L.A.; Schneider, M.; Massing, U. Health effects of dietary phospholipids. Lipids Health Dis. 2012, 11. [CrossRef] [PubMed]

56. Kraffe, E.; Soudant, P.; Marty, Y.; Kervarec, N. Docosahexaenoic acid-and eicosapentaenoic acid-enriched cardiolipin in the Manila clam Ruditapes philippinarum. Lipids 2005, 40, 619-625. [CrossRef] [PubMed]

57. Nagan, N.; Zoeller, R.A. Plasmalogens: Biosynthesis and functions. Prog. Lipid Res. 2001, 40, $199-229$. [CrossRef]

58. Jing, K.; Wu, T.; Kyu, L. Omega-3 polyunsaturated fatty acids and cancer. Anticancer Agents Med. Chem. 2013, 13, 1162-1177. [CrossRef] [PubMed]

59. Nabavi, S.F.; Bilotto, S.; Russo, G.L.; Orhan, I.E.; Habtemariam, S.; Daglia, M.; Devi, K.P.; Loizzo, M.R.; Tundis, R.; Nabavi, S.M. Omega-3 polyunsaturated fatty acids and cancer: Lessons learned from clinical trials. Cancer Metastasis Rev. 2015, 34, 359-380. [CrossRef] [PubMed]

60. Eckert, G.P.; Lipka, U.; Muller, W.E. Omega-3 fatty acids in neurodegenerative diseases: Focus on mitochondria. Prostaglandins Leukot. Essent. Fat. Acids 2013, 88, 105-114. [CrossRef] [PubMed]

61. Baum, S.J.; Kris-Etherton, P.M.; Willett, W.C.; Lichtenstein, A.H.; Rudel, L.L.; Maki, K.C.; Whelan, J.; Ramsden, C.E.; Block, R.C. Fatty acids in cardiovascular health and disease: A comprehensive update. J. Clin. Lipidol. 2012, 6, 216-234. [CrossRef] [PubMed]

62. Lorente-Cebrián, S.; Costa, A.G.V.; Navas-Carretero, S.; Zabala, M.; Martínez, J.A.; Moreno-Aliaga, M.J. Role of omega-3 fatty acids in obesity, metabolic syndrome, and cardiovascular diseases: A review of the evidence. J. Physiol. Biochem. 2013, 69, 633-651. [CrossRef] [PubMed]

63. Sirtori, C.R.; Galli, C. n-3 Fatty acids and diabetes. Biomed. Pharmacother. 2002, 56, 397-406. [CrossRef]

64. Gil, A. Polyunsaturated fatty acids and inflammatory diseases. Biomed. Pharmacother. 2002, 56, 388-396. [CrossRef]

(C) 2016 by the authors; licensee MDPI, Basel, Switzerland. This article is an open access article distributed under the terms and conditions of the Creative Commons Attribution (CC-BY) license (http:/ / creativecommons.org/licenses/by/4.0/). 